\title{
"Corporate diversity and corporate social environmental disclosure of listed manufacturing companies in Nigeria"
}

\begin{tabular}{|c|c|}
\hline \multirow{8}{*}{ AUTHORS } & Ozordi Emmanuel (D https://orcid.org/0000-0001-6628-8631 \\
\hline & R http://www.researcherid.com/rid/G-2971-2018 \\
\hline & Uwalomwa Uwuigbe (i) https://orcid.org/0000-0001-8769-3492 \\
\hline & R http://www.researcherid.com/rid/G-2903-2018 \\
\hline & Obarakpo Teddy (D) https://orcid.org/0000-0001-9579-4373 \\
\hline & R http://www.researcherid.com/rid/G-3098-2018 \\
\hline & Ikumapayi Tolulope (D https://orcid.org/0000-0001-6451-7875 \\
\hline & Gbenedio Akpevwenoghene Eyitomi (D https://orcid.org/0000-0002-4503-7574 \\
\hline ARTICLE INFO & $\begin{array}{l}\text { Ozordi Emmanuel, Uwalomwa Uwuigbe, Obarakpo Teddy, Ikumapayi Tolulope } \\
\text { and Gbenedio Akpevwenoghene Eyitomi (2018). Corporate diversity and } \\
\text { corporate social environmental disclosure of listed manufacturing companies in } \\
\text { Nigeria. Problems and Perspectives in Management, 16(3), 229-244. doi: } \\
\text { 10.21511/ppm.16(3).2018.19 }\end{array}$ \\
\hline DOI & http://dx.doi.org/10.21511/ppm.16(3).2018.19 \\
\hline RELEASED ON & Friday, 10 August 2018 \\
\hline RECEIVED ON & Monday, 19 March 2018 \\
\hline \multirow[t]{2}{*}{ ACCEPTED ON } & Wednesday, 23 May 2018 \\
\hline & $(c c) \overline{E Y-N C}$ \\
\hline LICENSE & $\begin{array}{l}\text { This work is licensed under a Creative Commons Attribution-NonCommercial } 4.0 \\
\text { International License }\end{array}$ \\
\hline JOURNAL & "Problems and Perspectives in Management" \\
\hline ISSN PRINT & $1727-7051$ \\
\hline ISSN ONLINE & $1810-5467$ \\
\hline PUBLISHER & LLC "Consulting Publishing Company "Business Perspectives" \\
\hline FOUNDER & LLC “Consulting Publishing Company "Business Perspectives" \\
\hline
\end{tabular}

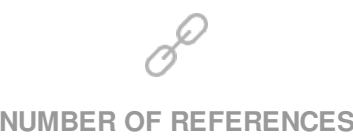

80

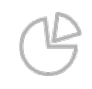

NUMBER OF FIGURES

1

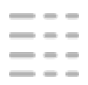

NUMBER OF TABLES

7

(C) The author(s) 2022. This publication is an open access article. 


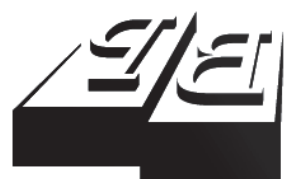

BUSINESS PERSPECTIVES

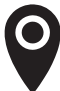

LLC “CPC "Business Perspectives" Hryhorii Skovoroda lane, 10, Sumy, 40022, Ukraine

www.businessperspectives.org

Received on: $19^{\text {th }}$ of March, 2018 Accepted on: $23^{\text {rd }}$ of May, 2018

(c) Ozordi Emmanuel, Uwalomwa Uwuigbe, Obarakpo Teddy, Ikumapayi Tolulope, Gbenedio Akpevwenoghene Eyitomi, 2018

Ozordi Emmanuel, Department of Accounting, Covenant University Ota, Nigeria.

Uwalomwa Uwuigbe, Department of Accounting, Covenant University, Ota-Ogun State, Nigeria.

Obarakpo Teddy, Department of Accounting, Covenant University Ota, Nigeria.

Ikumapayi Tolulope, Department of Accounting, Covenant University Ota, Nigeria.

Gbenedio Akpevwenoghene Eyitomi, Department of Accounting, Covenan University Ota, Nigeria.

\section{(ㄷ)(1) $(8)$}

This is an Open Access article, distributed under the terms of the Creative Commons Attribution-NonCommercial 4.0 International license, which permits re-use, distribution, and reproduction, provided the materials aren't used for commercial purposes and the original work is properly cited.

Ozordi Emmanuel (Nigeria), Uwalomwa Uwuigbe (Nigeria), Obarakpo Teddy (Nigeria), Ikumapayi Tolulope (Nigeria), Gbenedio Akpevwenoghene Eyitomi (Nigeria)

\title{
CORPORATE DIVERSITY AND CORPORATE SOCIAL ENVIRONMENTAL DISCLOSURE OF LISTED MANUFACTURING COMPANIES IN NIGERIA
}

\begin{abstract}
This study examined the impact of corporate diversity on corporate social environmental disclosure of registered manufacturing firms in Nigeria. The study considered both industrial and consumer goods firms, respectively, consisting a total of 37 firms. A total of 17 firms was selected for this study using purposive random sampling spanning the period 2012-2016. While the content analysis technique was engaged to ascertain the extent of corporate social environmental disclosure, the study adopted the following variables (board size, foreign directors, and gen der) as measures for corporate diversity. Findings from the study revealed that board size, foreign directors and gender had a significant positive influence on the extent of corporate social environmental disclosure of the selected firms. On the other hand, the presence of an independent director and non-executive director had an insignificant positive influence on corporate social environmental disclosure. Thus, the study recommends that a large and diverse board with experience, expertise and women involvement would enhance mandatory environmental audit and environmental grievance mechanism report, and if necessary, an ecological committee would be established, and also community leader on the board would contribute enormously to the going concern of the business.
\end{abstract}

\section{Keywords}

\section{JEL Classification}

\section{INTRODUCTION}

Corporate managers were charged with maximizing shareholders wealth within legal bounds. The drive of maximizing shareholders wealth led to the neglect of other stakeholders such as the society, plant, ecosystem and the environment where the business is situated (Balabanis, Philips, \& Lyall, 1998; Uwuigbe, et al., 2017). This idea was rather short lived at the advent of an increasing industrial revolution, having so much impact on the host community, ranging from global warming, large emission of greenhouse gases, and disposal of toxic wastes, which stirred up stakeholder's interest on corporate environmental reporting (Anderson, 1989). Today, corporate social and environmental reporting has become a crucial and voluntary global reporting initiative adopted by most developed countries across the globe, nevertheless developing country such as Nigeria is yet to fully ascribe to this environmental concerns (Azzone, Manzini, \& Noci, 1996). Ismail and Ibrahim (2008) opined that corporate social environmental reporting (CSER) in 
Jordan has experienced a creeping growth in implementation by corporations. Thereby, resulting in stakeholder's lack of public awareness, high violation of local community rights despite new sets of regulations governing business operations. However, developing economies like Nigeria share similar experiences.

The outburst of corporate social environmental disclosure has helped to solve environmental issues ranging from environmental pollution, environmental litigation to proper environmental accounting and reporting. However, the success of this reporting also led to global concern on how to harmonize accounting and environmental reporting costs and liabilities (Pramanik, Shil, \& Das, 2008). Notwithstanding the challenges of harmonizing accounting and environmental reporting costs, Thomas and Hunger (2008) as cited in Tareq, Reza, and Hassan (2017) opined that corporations should strive to be socially responsible, because building a good image is key to the survival of a business, and when this is done, it transcends to a long-lasting relationship with diverse stakeholders, which is ideal for a perpetual and sustainable business environment.

Traditionally, corporate social environmental engagement has drawn lots of attention recently, but social environmental disclosure report is voluntary in nature. However, the voluntary nature of such reports could mere the credibility of this report reason been that some organization may not be willing to disclose such information or rather not disclose at all or partially disclose environmental information. In the context of Nigeria, we could observe lots of companies not fully providing adequate social environmental information in their annual reports. However, this study seeks to find out what could be responsible for this poor participation by Nigerian firms. Sharfman and Fernandoi (2008), Mgbame (2012) as cited in Ndukwu and John (2015) opined that factors such as leverage, industry type, profitability, firms size could possibly influence organizations to voluntarily engage in social environmental disclosures. Having suggested this by Sharfman and Fernando (2008), Mgbame (2012), the cultural orientation of countries also could be responsible for the poor response.

However, lots of works have scrutinized the influence of board composition on company economic performance with less attention to non-financial performance indicators (Carter, Simkins, \& Simpson, 2003; Rose, 2007) as cited in Kathyayini Rao, Tilt, and Lester (2016). The diversity and composition of members on the board with relevant skills, technical intelligence, and external exposure would facilitate quality and a more improved decision-making process, aimed at increasing the level of company's policy towards corporate social and environmental disclosure (Strandberg, 2005; Mackenzie, 2007). In the same vein, Alfken, Bellar, and Helms (2004) as cited in Lilik, Bambang, Sutrisna, and Erwin (2014) asserted that the absence of board diversity led to the failure and weakness of governance in corporations and admonished that a diverse board would enhance the quality of decision making at top level management, promote high ethical standards, reduce narrow-minded decisions, and improve corporate strategic planning and accountability. Corkery and Taylor (2012) opined that corporate diversity and equal representation on the board would encourage better ethical behavior and reduce fraud so as to greatly reduce agency cost. However, a gap in literature exists on how a corporately diverse board would impact the level of the firm's social environmental reporting in the manufacturing sector of the Nigerian economy.

To answer the question raised, the arrangement of this study will take this particular order. The first section of the paper reflects well develop and examine extant literature. The second part explains the empirical data collection method used for the analysis. Furthermore, data derived would be analyzed. However, we present a discussion, conclusions and recommendations for imminent research. 


\section{LITERATURE REVIEW AND HYPOTHESES DEVELOPMENT}

\subsection{Corporate diversity}

Corporate diversity has so much influence on the quality of the board (Kruger, 2007; Osariemen et al., 2018). Diversity would foster conflict of interest, different opinion, and knowledge, but all these shortfalls are considered ideal for a good board composition aimed at providing quality and value of organization decision-making process geared toward improving the level of environmental disclosure (Carter, Simkins, \& Simpson, 2003; Jackson, Joshi, \& Erhardt, 2003). Another school (Campbell \& Minguez-Vera, 2008) opined that board diversity could be determine using demographic classification which consists of age, nationality, ethnicity, gender, educational history, work experience, and organizational membership. However, Jackson et al. (2003) had a contrary opinion that both schools are making emphasis on the same measure on diversity, that a quality board should ensure multiple diversity dynamism purposely to safeguard the dynamic needs of various parties (stakeholders).

\subsection{Corporate social environmental disclosure}

Corporate social environmental disclosure can be broken down into two constructs, namely social information and environmental information, respectively, and the major drive is to ensure that both societal and environmental performance of an organization is well disclosed to its stakeholders (Thompson \& Zarina, 2004). Social disclosure consists of releasing information geared at enhancing human resources in form of workers skill acquisitions, improvement, wellbeing and security, equal privilege and wages fairness, tailoring consumers concerns (customer well-being and security, consumers criticisms and compliance with product laws), safeguarding human right (freedoms to express ourselves, non-discrimination), and tailoring other concerns of various stakeholders and community members by reducing corruption, enacting policies to frown at any form of unhealthy competition and conform with stated law
(GRI, 2011). Environmental reporting covers the efficient use of materials and recycling methods, direct and indirect energy consumption, perseveration of bio-diversity lifespan, possible policies towards reducing and treating of emissions, effluent, resources and waste management, and efforts made to reduce product and services environmental ill effects (GRI, 2011). However, the term "corporate social environmental disclosure" is a deliberate step taken by an organization to extensively provide information on a symbiotic association between the firm activities and its immediate environments.

\subsection{Theoretical framework}

There is various literature having identical ontological views on corporate social environmental accounting such as the legitimacy, stakeholder, agency and resources dependency theory. Chen and Robert (2010) opined that the theories stated are system centred theories, which claim every firm is influenced by their immediate environment in which they are located, therefore deliberate efforts should be made by these organizations to reduce risk and ensure long-term sustainability and growth. This work would use the resource dependency theory as the theory that would guide the paper in lieu of finding out the effect a corporate diverse board has on the quality of social environmental reporting of registered manufacturing companies on the Nigerian stock market.

\subsection{Resource dependency theory}

Resource dependency theory provides an insight on how firms are responsible for contributing to the firms' internal and external benefits. Preffer and Salancik (1978) as cited in Lilik, Bambang, Sustrisno, and Erwin (2014) opined that companies influence business environment by selecting resources useful to their going concern (existence). In line with this view, Lynall, Golden, and Hilman (2003) were of the opinion that businesses are open system affected by its environment, and to attain a long-term existence, the quality of the board must play a very crucial role in harmonizing diverse interest of stakeholders. Duztas (2008) asserted that the selection of resources used up by the organization is determined by the board. Therefore, the quality of the board would help strike a balance be- 
tween the interest of the company and that of the business environment. Carpenter, Geletkanycz, and Sanders (2004), Selsky and Parker (2005) avowed that corporate board are also resources that bring on expertise, experience, ideas and a set of experience board would help build a formidable relationship with its stakeholders and external environment targeted at a long-term sustainability.

\subsection{Agency theory}

Agency theory creates a structure that links corporate diversity to social environmental reporting. This theory expresses the interplay of contractual agreement that exists between an agent (manager) and the owner of the investment. The agent (directors) are in charge of supervising and monitoring the internal affairs and the management of managers on behalf of shareholder and stakeholders (Mclkenny \& Ben-Amar, 2015; Uwuigbe, 2017). The theory suggests that a more diverse board would reduce the chances of agency cost.

\subsection{Agency theory and board size}

Ntim, Lindop, and Thomas (2013) opined that the size of a board has a higher propensity of improving the voluntary information including environmental disclosure, agency theorist are of the opinion that a more diverse board would possess more expertise, qualities and core competence needed to ensure adequate monitoring and supervisory of management (Larmou \& Vafeas, 2010; Uwigbe, Egbide, \& Ayokunle, 2011; Salama, Sun Hussainey, \& Habbash, 2010; Olubukola et al., 2016). In line with Elzahar and Hussainey (2012), they avowed that a large board composition has a higher proximity of increasing the volume of directors who are experienced in financial and accounting matters, thereby enhancing company social environmental information. Empirical studies carried out by Haji (2012), Cheng and Courtenay (2006), Hidalgo, Garcia-Meca, and Martinez (2011) all attested that a larger board influences the quality of environmental information. Furthermore, Sadia et al. (2015) found a positive and strong relationship between the board size and the level of social environmental disclosure in Pakistan spanning the period 2007-2011. This findings collaborate the work of Ezhilareasi and Kabra (2017) in China spanning the period 2009-2015.
In a similar context, Jensen (1993) opined that a larger board does not guaranty effectiveness and could be manipulated by the CEO when compared to a smaller board. He opined that a larger board has a higher proximity to supervizing and controlling activities notwithstanding, but can be outweighed when compared with the cost of poor communication and delay in verdict making. Kathyayini et al. (2012) asserted that the quality of the content disclosed needs to be properly communicated and coordinated in an effective and efficient manner amongst board members. Hence, larger board could reflect an adverse effect on the quality content of environmental reporting. These arguments were supported by empirical studies such as Bouaziz (2014) and UwUigbe et al. (2011) who opined that a larger board would create room for free riders which would make agency problem to be on a rise. Saha and Akter (2013), and Arcay and Vazquez (2005) as cited in Halil (2016) carried out an empirical study to ascertain the influence a large board has on deliberate disclosure, but conclude that a non-significant relationship exists amid both variables under study. Therefore, a deviation exists between the theoretical framework and the empirical findings.

Ho1: There is no significant association between board size and the extent of corporate social environmental reporting.

\subsection{Agency theory and board independence}

Board independence is a crucial corporate governance structure that determines an organization extent of social environmental reporting (Khan, Muttakin, \& Siddiqui, 2014). The board usually consists of both dependent directors and independent directors. Independent directors are the minority interest group (shareholders), because they do not engage in the daily activities of the board they are mere ally with their executive position (Mohamad \& Sulong, 2010; Rouf, 2011), the dependent directors who have a larger involvement with the firm's activities.

Agency theory opined an increase in the proportion of independent director would prompt an increase in effectively controlling and monitoring the board and management, respective- 
ly (Chau \& Gray, 2010). Sharif and Rashid (2014), Khan (2010) asserted that a higher percentage of non-dependent executives present would create a balance of interest and ensure that company's policies and programs capture the interest of shareholders, stakeholders and the environment at large. Furthermore, Alhassan and Basariah (2016) averred that enlightened independent directors would improve environmental reporting.

In line with the theory, Uwuigbe et al. (2011) as cited in Halil (2016) avowed that corporate social environmental reporting would only see the limelight by having a larger proportion of outsider directors other empirical studies align with this claims are (Gisbert \& Navallas, 2013; Arcay \& Vazquez, 2005).

Ho2: There is no relationship between independent and non-executive directors on the level of corporate social environmental reporting.

\subsection{Agency theory and gender diversity}

It would interest you to know that the male gender differs from the female gender culturally and socially, and these changes tend to trigger the relevance of women participation on the quality of environmental reporting (Liao, Luo, \& Tang, 2014). An increased percentage of females on the board would foster business interactions resulting to an increase in environmental information (Barako \& Brown, 2008). Bowrin (2013) averred that adequate representation of female would improve company diversity, socio-economic interaction with the business environment (Natividad, 2005). Went further to amplify the need for female director saying that the psychological and compassionate attribute makes them stand up for less powerful stakeholders. Furthermore, Diamantopoulos et al. (2003), Rahman and Post (2012) all averred that most female directors pay more attention to social activities relating to donations, educational supports and aids to non-governmental institutions, rather than environmental issues. However, Alazzani, Hassanein, and Aljanadi (2017) found a positive relationship amid social performance and female directors on the board in Malaysian firms. This findings all collaborates the work of Dienes and Velte (2016), Kılıç, Kuzey, and Uyar (2015).
Consequently, Konrad, Kramer, and Erkut (2008) carried out a research and discovered that the presence of only one woman on the board undermines her willingness to freely express her opinion on environmental issues and the involvement of more than one would participate formidably. In concordance with it Ruply et al. (2012) avowed that women present in a company structure would influence deliberately social environmental reporting. Bernardi and Threadgill (2010), Gallén and Perait (2017), asserted that gender diversity has the ability to enhance decision-making process and provide better information on dealing with environmental and ethical issues, respectively.

Ho3: There is no relationship between the presence of women on the board and the level of corporate social environmental disclosure.

\subsection{Foreign directors}

The agency theorists are of the opinion that a more diverse board with expertise and experience would reduce future agency problems and ensure that owner's resources are managed effectively. The foreign directors considered in the study are personnel from developed countries that pay more interest on social environmental matters. In the same vein, they are willing to transfer such acquired knowledge to the domestic developing countries such as Nigeria. Fields and Keys (2003) are of the opinion that for an organization to acquire diverse innovations, skills, ideas, it should employ the services of individuals from different parts of the world. Giannetti, Liao, and Yu (2015) are of the opinion that foreign director's expertise and experience over time would improve firm's performance, because they have better exposure on global happenings and they are not influenced by domestic directors and this would ensure effective monitoring of information being disclosed. In the same vein, Masulis, Wang, and Xie (2012) opined that the exposure, skills and knowledge power of a foreign board member would increase the chances of the firm identifying new business opportunities, expansion and detailed information on the environment. Giannetti et al. (2015) opined that a positive relationship exists between returnee managers on corporate social performance, he went further to say that board of directors with foreign exposure and experience would 
replicate such level of experiences in governance and management of decision-making processes, which would have an effect on the level and quality of environmental information.

Khan (2010) carried out a research in Bangladesh Bank and opined that foreign directors in the board improved the quality of banks social environmental information. In disparity, a similar case of Kenya banks responded otherwise. This was found in a work carried out by Barako and Brown (2008) who opined that foreign directors in the board has no influence on the social and environmental disclosure made by the banks. He further went on to buttress his claims by assuming that the foreign directors would have a major objective, which is to protect the interest of the foreign owners rather than focus on voluntary disclosures.

Ho4: There is no relationship between foreign directors in the board and the quality of corporate social environmental disclosure.

\section{MATERIALS AND METHODS}

An ex-post facto research approach was adopted in order to attain the objectives of the study. This section discusses the modalities adopted in the development of the study. It includes the population, sample, data collection, measurement of the variables.

\subsection{Sample selection, data collection and analysis}

In order to attain the overall objective of this study, seventeen (17) firms were selected from a total of thirty seven (37) listed industrial and consumer goods firm spanning through the period 2012-2016. The choice of these seventeen companies was based on their frequent tracks or traits of a constantly high level of production capacity, which could possibly affect the environment in which these companies are located (Oyeshola, 2008). Based on this specification, and guided by Kerjice and Morgan (1970) assumptions as cited in Uwuigbe, Olusanmi, and Iyoha (2015) who are of the opinion that a minimum of $5 \%$ of a well-defined population is considered a sufficient sample size suitable for generalization. In lieu of Kerjice and Morgan (1970), seventeen manufacturing firms were selected (see appendix for sampled firms). This study relies solely on listed firms because of the ease of accessing company's annual report and because these companies are obliged to do so annually. However, content analysis was used to capture the extent of the sampled firm's social environmental disclosure. The Eviews statistical software was used to analyze the data.

\subsection{Development of corporate social environmental disclosure index}

This reflects the dependent variable in this study and was derived from the manufacturing firms' corporate annual reports and official website spanning through the period 2012-2016. Extant literature have appraised Global Reporting Initiative (GRI) as a fore-runner for social environmental disclosure and many other sustainable reporting (Daizy \& Das, 2014). However, GRI has certain weaknesses as one of them has not been industry-specific, notwithstanding these challenges, this work used the GRI template and other extant literature works checklist experiencing similar situation with Nigeria (developing economies). This gave rise to an eighteen (18) checklist adopted for this study (see template in Appendix). However, the unweighing approach was used to score disclosed items in order to ensure that all items are adequately represented and free from subjectivity and bias, items not disclosed are scored 0 , while items disclosed are scored 1. Prior works that adopted the unweight method in counting disclosed items includes Hamid and Atan (2011), Amran and Haniffa (2011), Esa and Ghazali (2012), Ahmad and Haraf (2013), and Haji (2013), as cited in Michelle Phua Siew Huei (2016).

The CED checklist was derived from earlier researchers and GRI standards, all items on the list are allotted a mark of 1 , if disclosed in the yearly reports, or 0 mark, if absent. As soon as every item is allotted marks, the marks are then summed up to examine the extent of items disclosed in each sampled firm. The summed items are then alienated by the entire sum of items as contained in the checklist in order to determine the percentage to which the sampled firms disclose their environmental activities. This is calculated as follows: 
Table 1. Measurement

\begin{tabular}{|c|c|c|}
\hline Variable & Item (proxies) & Measurement \\
\hline Dependent & $\begin{array}{l}\text { Corporate social environmental } \\
\text { disclosure (CSED) }\end{array}$ & Total items disclosed/maximum (18) items (see Appendix A) \\
\hline \multirow{4}{*}{ Independent } & Board size (BSIZE) & Actual directors on the company structure yearly \\
\hline & Board independence (BIND) & $\begin{array}{l}\text { Percentage of independent and non-executive directors alienated by the } \\
\text { entire sum of directors present yearly }\end{array}$ \\
\hline & Gender diversity (GD) & $\begin{array}{l}\text { The proportion of women directors divided by the Actual executives on } \\
\text { the board }\end{array}$ \\
\hline & Foreign director (FD) & $\begin{array}{l}\text { The percentage of a non-Nigerians on the board divided by the total } \\
\text { board members }\end{array}$ \\
\hline
\end{tabular}

$C E D=$ The sum of items disclosed

in the firm's yearly report · $100 \%$,

Total number of items on the disclosed list

\subsection{Independent variables (corporate diversity)}

The corporate diversity is considered the autonomous variables in this work, which include gender diversity, board independence, size of the board, and foreign director. The information on corporate diversity is derived from the yearly reports of these firms. Board size (BSIZE) is determined by the actual directors present yearly. Board independence (BIND) is calculated by the percentage of independent and non-executive to board size. Foreign director (FD) is calculated by dividing the proportion of non-Nigerians on the board by the total board members, gender diversity (GD) was ascertained as a proportion of female executives on the total number of executives on the board.

\subsection{Model specification}

The study has certain hypotheses stated above, hence, the model was adopted from the work (Halil, 2016) in order to examine the level in which a corporately diverse board has on the quality of social environmental reporting.

The equation is calculated implicitly as follows:

$$
C S E D_{i t}=f\left(B S I Z E_{i t}, B I N D_{i t}, G D_{i t}, F D_{i t}\right),(1)
$$

where $i$ - number of observations, $t$ - time period, $C S E D_{i t}$ - is calculated by adopting the 18 environmental checklist items guided by GRI,
$B S I Z E_{i t}$ - represents the size of the board present yearly, $B I N D_{i t}$ - represents the fraction of independent and non-executive directors divided by the actual executives on the board yearly, $G D_{i t}$ - represents the proportion of women executives divided by the actual executives on the board yearly, $F D_{i t}$ - represent the proportion of non-Nigerian directors divided by the entire board members.

To ensure that the model identified above contain statically significant variables, we used stepwise-backwards procedure. Under this method, the variables are first included in the model, then variables are removed based on the $p$-value criterion. Hence, the variables with $p$-value higher than the set criterion are removed. The result of this section technique is shown in Table 2.

The results of the stepwise regression show that the BIND (board independence) variable is not statistically significant to the model, therefore, it was removed. The model can be rewritten and expressed explicitly as follows:

$$
\begin{aligned}
& C S E D_{i t}=\beta_{i}+\delta_{t}+\beta_{1} B S I Z E_{i t}+ \\
& +\beta_{2} G D_{i t}+\beta_{3} F D_{i t}+\mu_{i t},
\end{aligned}
$$

where $i$ - denotes firms specific, $t$ - denotes the deterministic time trend, $\mu_{i t}-$ denotes the estimated residual.

\section{Validity and reliability}

The data were derived from each of the sampled firm annual reports and official website, however, content analysis was used to determining the 
Table 2. Stepwise regression

Dependent variable: CSEDI

Included observations: 85

Number of always included regressors: 1

Number of search regressors: 4

Selection method: stepwise backwards

Stopping criterion: $\mathrm{p}$-value forwards/backwards $=0.05 / 0.05$

\begin{tabular}{|c|c|c|c|c|}
\hline Variable & Coefficient & Std. Error & T-statistic & Prob.* \\
\hline C & -0.322695 & 0.096478 & -3.344748 & 0.0012 \\
\hline BSIZE & 0.060756 & 0.007812 & 7.777195 & 0.0000 \\
\hline GENDER & 0.866844 & 0.129988 & 6.668647 & 0.0000 \\
\hline FD & 0.241031 & 0.105397 & 2.286900 & 0.0248 \\
\hline R-squared & 0.543172 & \multicolumn{2}{|c|}{ Mean dependent var } & 0.545752 \\
\hline Adjusted R-squared & 0.526252 & \multicolumn{2}{|c|}{ S.D. dependent var } & 0.270429 \\
\hline S.E. of regression & 0.186134 & \multicolumn{2}{|c|}{ Akaike info criterion } & -0.478781 \\
\hline Sum squared resid & 2.806325 & \multicolumn{2}{|c|}{ Schwarz criterion } & -0.363832 \\
\hline Log likelihood & 24.34818 & \multicolumn{2}{|c|}{ Hannan-Quinn criter. } & -0.432545 \\
\hline F-statistic & 32.10318 & \multicolumn{2}{|c|}{ Durbin-Watson stat } & 0.766373 \\
\hline Prob (F-statistic) & 0.000000 & & & \\
\hline \multicolumn{5}{|l|}{ Selection summary } \\
\hline \multicolumn{2}{|l|}{ Removed BIND } & & & \\
\hline
\end{tabular}

extent of the sampled firm social environmental disclosure. The checklist used to ascertain the extent disclosure was derived from global reporting initiative and used in the works of Michelle (2016), Ahmad and Haraf (2013), Haji (2013), Halil (2016).

\section{RESULTS AND FINDINGS}

The result from the descriptive statistics as shown below in Table 3 presents a mean on corporate social environmental disclosure of .54575 of the selected manufacturing companies under study. This shows an average percentage distribution of $54.5 \%$, based on the figure obtained from these firms' annual report a range of 0.2 to 0.944 variation exist in the level of these firms' environmental reports, which reflect that more attention is paid to the quality of environmental reporting from these selected firms. In the same vein, the independent variables, which are the BSIZE, GENDER, FOREIGN DIRECTORS, show an average mean value of $10.58, .634, .16$ and .323 , separately, from the sampled industries. The result of the average board size indicates that about 11 persons are on the board. The board size number corresponds with Security and Exchange Commission (SEC) requirement. Corporate Governance Code (2014) clearly states that the board size must have at most six directors on the board and at least twenty directors. However, the gender and foreign directors show that female directors constitute about $16 \%$, and $32 \%$ is for foreign directors, respectively, of the sampled firm. Furthermore, the histogram normality chart clearly depicts that the data used for this study were normally distributed. However, this is seen by 0.11 greater than the $5 \%$ significance level.

Table 4 presents the correlation matrix of the independent and dependent variables, respectively. It clearly depict that a linear association exists amid the explanatory variables. According to Gujarati (2004), multicollinearity could only be a problem if the pair-wise correlation coefficient among regressors is above 0.80 . However, this independent variable in this study is free from any visible traits of multicollinearity. Consequently, the result shows that board size (BSIZE) has firm and positive relationship with corporate social environmental disclosure. Subsequently, foreign director (FD) and gender (GD) follow.

\section{Interpretation}

The Hausman test was carried out to determine which model is appropriate for the panel regression. The fixed effects treat both $\alpha_{i}$ and $\delta_{t}$ as re- 
Table 3. Descriptive statistics

Source: Calculated by the researchers using the E-VIEWS 9 (2016).

\begin{tabular}{|c|c|c|c|c|}
\hline Variable & CSEDI & BSIZE & GENDER & FD \\
\hline Mean & 0.545752 & 10.58824 & 0.169787 & 0.323472 \\
\hline Median & 0.388889 & 10.00000 & 0.125000 & 0.285714 \\
\hline Maximum & 0.944444 & 17.00000 & 0.750000 & 0.777778 \\
\hline Minimum & 0.222222 & 7.000000 & 0.000000 & 0.000000 \\
\hline Std. Dev. & 0.270429 & 2.638064 & 0.158457 & 0.192922 \\
\hline Skewness & 0.429971 & 1.027389 & 1.270212 & 0.353026 \\
\hline Kurtosis & 1.516464 & 3.293137 & 4.890157 & 2.522967 \\
\hline Jarque-Bera & 10.41384 & 15.25765 & 35.51033 & 2.571499 \\
\hline Probability & 0.005479 & 0.000486 & 0.000000 & 0.276443 \\
\hline Sum & 46.38889 & 900.0000 & 14.43188 & 27.49511 \\
\hline Sum Sq. Dev. & 6.143065 & 584.5882 & 2.109112 & 3.126379 \\
\hline Observations & 85 & 85 & 85 & 85 \\
\hline
\end{tabular}

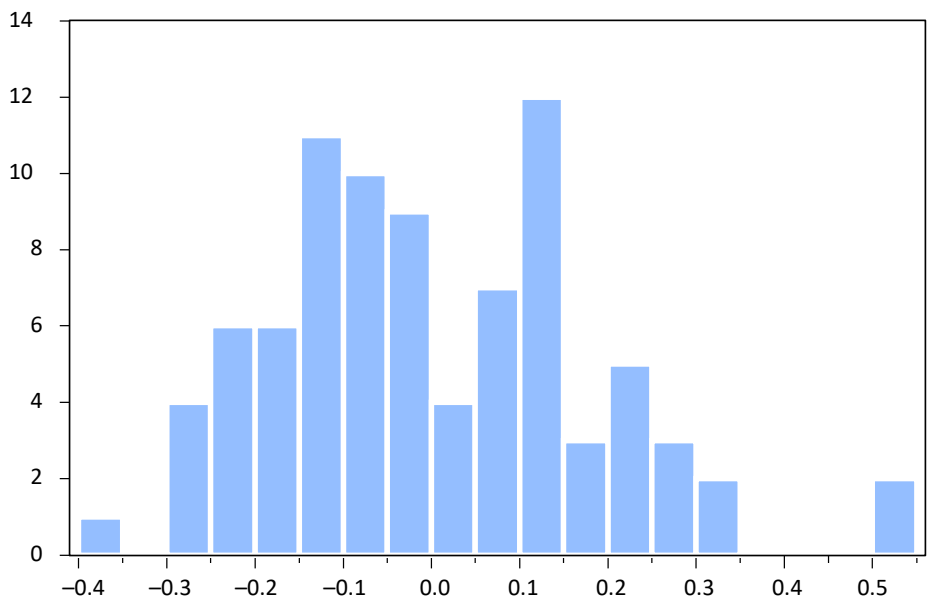

Series:

Sample

Observations

Mean

Median

Maximum

Minimum

Std. Dev.

Skewness

Kurtosis

Jarque-Bera

Probability
Standardized Residuals

2012-2016

85

$1.46 \mathrm{e}-16$

$-0.031261$

0.529807

$-0.380857$

0.180770

0.537120

3.252808

4.313402

0.115706

Figure 1. Histogram normality

Table 4. Correlation matrix

Source: Calculated by the researchers using the E-VIEWS 9 (2016).

\begin{tabular}{|c|c|c|c|c|}
\hline Correlation & CSEDI & BSIZE & FD & GEN \\
\hline CSEDI & 1.000000 & - & - & - \\
\hline BSIZE & 0.516211 & 1.000000 & - & - \\
\hline FD & 0.183389 & 0.043867 & 1.000000 & - \\
\hline GEN & 0.404958 & -0.165410 & -0.028666 & 1.000000 \\
\hline
\end{tabular}

Table 5. Hausman test

Source: Calculated by the researchers using the E-VIEWS 9 (2016).

\begin{tabular}{|c|c|c|c|}
\hline \multicolumn{4}{|c|}{ Correlated random effects - Hausman test } \\
\hline \multicolumn{4}{|l|}{ Equation: untitled } \\
\hline \multicolumn{4}{|c|}{ Test period random effects } \\
\hline Test summary & Chi-Sq. Statistic & Chi-Sq. d.f. & Prob. \\
\hline Period random effects & 3.414077 & 3 & 0.3321 \\
\hline
\end{tabular}


gression parameters, whereas random effects treat them as components of the error term. However, the Hausman test rule states that if the $p$-value is statistically significant, the alternative hypothesis (fixed effects model) is accepted, whereas, if the $p$-value isn't statistically significant, the null hypothesis (random effects model) is accepted.

From the analysis, it is seen that the $p$-value (0.3321) 5\% significance level, so the null hypothesis is accepted, which advocates that the random effects model is greater than be used for the regression analysis.

Table 6. Regression result for (panel fixed effects can estimation)

Source: Compiled by researcher using E-VIEWS 9.

\begin{tabular}{|c|c|c|}
\hline Variables & Fixed effects & Random effects \\
\hline BSIZE & $\begin{array}{c}0.0629542 * * * \\
(7.914699)\end{array}$ & $\begin{array}{c}0.060756^{* * *} \\
(7.749015)\end{array}$ \\
\hline FD & $\begin{array}{l}0.264178^{* *} \\
(2.475776)\end{array}$ & $\begin{array}{l}0.241031^{* *} \\
(2.278614)\end{array}$ \\
\hline GENDER & $\begin{array}{l}0.901495^{* *} \\
(6.819119)\end{array}$ & $\begin{array}{l}0.866844 * * * \\
(6.644484)\end{array}$ \\
\hline $\mathrm{C}$ & $\begin{array}{l}-0.354971 \\
(-3.607011)\end{array}$ & $\begin{array}{c}-0.322695^{* * *} \\
(-3.332628)\end{array}$ \\
\hline R-squared & 0.562567 & 0.543172 \\
\hline F-statistic & 14.14671 & 32.10318 \\
\hline Prob (F-statistic) & 0.000000 & 0.000000 \\
\hline Hausman statistics & 0.3321 & - \\
\hline
\end{tabular}

Note: $T$-statistics are in parentheses, ${ }^{\star} p<0.10,{ }^{* *} p<0.05,{ }^{* * *}$ $p<0.01$.

\section{DISCUSSION OF PANEL REGRESSION RESULT}

The random effects model was considered more suitable model for the panel regression analysis. However, using the random effects model from the table above, the independent variables are harmoniously capable of explaining about $54 \%$ of the selected industries social environmental disclosure, which infers that only $54 \%$ of the independent variables are capable of predicting our dependent variables. The remaining percent can be ascribed to other factors not considered in this study. Furthermore, the Fisher ratio shows a $p$-value less than 0.05 (i.e. $0.000000<0.05$ ); this implies that the relationship between the explanatory variables and the dependent variables is linear, also buttressing that the independent variables are simultaneously and significantly associated with the dependent variable.
Table 6 depicts the relationships between the explanatory variables and the dependent variable as used in this study. Findings for the first hypothesis (there is no relationship between the board size and the extent of social environmental reporting) show that a positive relationship between exists the size of the board and the extent of social environmental disclosure of the selected industries. This is evident in the $t$ - statistics value of 7.74 and a $p$-value less than 0.01 level of significance. This result indicates that the null hypothesis is rejected, while the alternate hypothesis is accepted. However, the addition of a director on the board would improve social environmental reporting by 0.060756, which also buttresses the claim that a more diverse board would possess more expertise, qualities and core competence needed to ensure adequate monitoring and supervision of management that would improve the quality of their corporate social environmental information to its stakeholders. This outcome corroborates the findings of Larmou and Vafeas (2010), Ntim et al. (2013), Elzahar and Husaney (2012), where they opined the fact that an increased board size has a higher proximity of increasing the volume of directors who are experienced in financial and accounting matters, thereby enhancing the quality and quantity of corporate social and environmental reporting.

Findings, as it relates to the second hypothesis (there is no relationship between the presence of women on the board and the level of corporate social environmental disclosure), show that the presence of women on the board has a significant influence on the level of voluntary information actually disclosed by firms. This is evident in the $t$-statistics of (6.64) and a $p$-value less than 0.01 level of significance, respectively. This outcome suggests the rejection of the null hypothesis, while the alternative hypothesis is accepted and clearly depicts that the presence of at least one woman on board would improve the social environmental disclosure by 0.866844 . It further implies that the presence of a minimum of three women at the top level management will help improve the sampled firms' social environmental disclosure. This outcome is in line with the findings of Kramer, Konrad, and Erkut (2008), where they averred that the presence of only one woman on the board undermines her willingness to freely express her 
opinion on environmental issues and the involvement of more than one would participate formidably. Bernardi and Threadgill (2010) also asserted that gender diversity has the ability to improve the value creation and provide better information on dealing with environmental and ethical issues, respectively.

Findings, as it relates to the third hypothesis, which states that there is no significant association between a foreign director on the board and the level of corporate social environmental disclosure, presents foreign experts on the board to have a significant positive influence on the voluntary reporting of the company. The $t$-statistics value of 2.27 and a $p$-value less than 0.01 level of significance support these findings. Hence, the null hypothesis was rejected. This outcome further suggests that as the number of foreign executives on top-level management increases, the level of voluntary disclosure would be enhanced, however, this is evident by the co-efficient of 0.241031 . This result is in line with the work of Barako and Brown (2008) and contradicts the findings of Giannetti, Liao, and $\mathrm{Yu}(2015)$ and Khan (2010).

\section{CONCLUSION AND RECOMMENDATIONS}

This work assessed the effect of corporate diversity on social environmental disclosure of listed manufacturing companies on the Nigerian stock market. Nevertheless, drawing from the hypotheses tested, the findings of this work revealed that all the stated corporate diversity proxies had a positive relationship with the company's social environmental reporting. The paper discovered that most of the sampled firms do not have an environmental audit report, and environmental grievance mechanism to provide a clear yardstick to examine the quality of their social environmental engagement. On the premises of this stated points, the paper concludes that listed industrial and consumer goods firms need to come out with ideas on how to tackle the direct effect of their activities on its immediate environment and must provide a symbiotic report. The paper therefore recommends that a large and diverse board with experience, expertise and women involvement would enhance mandatory environmental audit and environmental grievance mechanism report, and, if necessary, an ecological team in the company would be established, and possibly a community leader on the board would contribute enormously to corporate legitimacy and ensure corporate survival and success, as asserted by Hillman and Dalziel (2003), Sadia, Tariq, and Saba (2015). The paper only focused on two manufacturing firms, which are the industrial and consumer goods firms listed on the stock market. Other researchers could consider other sectors and other corporate diversity proxies not used in the study.

\section{NOVELTY AND CONTRIBUTION TO KNOWLEDGE}

This study contributes to knowledge by providing new dimension on the impact/role of gender and foreign directors in the disclosure of corporate social environmental information in Nigeria. Finding in this study makes a contribution by providing a detailed insight on the environmental disclosure level of manufacturing firms. Finally, the novelty of this study is demonstrated in the model, as it adds to existing literature on the role of gender and foreign in corporate environmental disclosure.

\section{FURTHER STUDIES}

Considering the fact that this study only looked that at the manufacturing companies (17 firms the industrial goods and consumer goods) in Nigeria is a major limitation for this study. Hence, this study suggests that future research in this area could address this salient limitation by examining listed firms in the Nigerian Stock Exchange (NSE) including those in the oil sectors of the Nigerian economy that are heavily involved gas flaring and high carbon dioxide emission $\left(\mathrm{CO}_{2}\right)$. 


\section{ACKNOWLEDGEMENT}

Authors acknowledge Covenant University who has solely provided the plate form for this research and has also fully sponsored publication of this research work.

\section{REFERENCES}

1. Ahmad, N., \& Haraf, A. (2013). Environmental Disclosure of Malaysian Property Development Companies: Towards Legitimacy or Accountability? Social Responsibility Journal, 9, 241-258. https://doi. org/10.1108/SRJ-10-2011-0090

2. Alazzani, A., Hassanein, A., \& Aljanadi, Y. (2017). Impact of gender diversity on social and environmental performance: evidence from Malaysia. Corporate Governance: The International Journal of Business in Society, 17(2), 266-283. https://doi.org/10.1108/ CG-12-2015-0161

3. Amran, A., \& Haniffa, R. (2011). Evidence in Development of Sustainability Reporting: A Case of a Developing Country. Business Strategy and the Environment, 20(3), 141-156. https://doi.org/10.1002/ bse. 672

4. Anderson, J. (1989). Corporate Social Reporting. New York: Quorum Books. Retrieved from https://trove.nla.gov.au/work/18798 444?q\&versionId=22068085

5. Arcay, M. R. B., \& Vazquez, M. F. M. (2005). Corporate characteristics, governance rules and the extent of voluntary disclosure in Spain. Advances in Accounting, 21, 299-331.

6. Arfken, D. E., Bellar, S. L., \& Helms, M. M. (2004). The ultimate glass ceiling revisited: The presence of women on corporate boards. Journal of Business Ethics, 50(2), 177-186. Retrieved from http:// www.academia.edu/907239/ The_ultimate_glass_ceiling_revisited_The_presence_of_women_on_ corporate_boards

7. Azzone, G., Manzini, R., \& Noci, G. (1996). Evolutionary Trend in Environmental Reporting. Business Strategy and the Environment, 5, 219-230. Retrieved from https://onlinelibrary.wiley.com/ doi/full/10.1002/(SICI)1099-
0836(199612)5:4\%3C219::AIDBSE69\%3E3.0.CO;2-K

8. Balabanis, G., Philips, H., \& Lyall, J. (1998). Corporate Social Responsibility \& Economic Performance in the Top of British Companies: Are they linked? European Business Review, 98, 25-44. Retrieved from https:// pdfs.semanticscholar.org/70ab/ bf7fcb427376a59bbc4c9722c6516 7c7b146.pdf

9. Barako, D. G., \& Brown, A. M. (2008). Corporate social reporting and board representation: evidence from the Kenyan banking sector. Journal of Management \& Governance, 12(3), 309-324. https:// doi.org/10.1007/s10997-008-9053-x

10. Ben-Amar, W., \& McIlkenny, P. (2015). Board effectiveness and the voluntary disclosure of climate change information. Business Strategy and the Environment, 24(8), 704-719. Retrieved from https:// econpapers.repec.org/RePEc:bla:bst rat:v:24:y:2015:i:8:p:704-719

11. Bernardi, R. A., \& Threadgill, V. H. (2010). Women directors and corporate social responsibility. Electronic Journal of Business Ethics and Organizational Studies, 15(2), 15-21. Retrieved from https://philpapers.org/rec/BERWDA-3

12. Bowrin, A. R. (2013). Corporate social and environmental reporting in the Caribbean. Social Responsibility Journal, 9(2), 259-280. https://doi.org/10.1108/SRJ-082011-0074

13. Campbell, K., \& Mínguez-Vera, A (2008). Gender Diversity in the Boardroom and Firm Financial Performance. Journal of Business Ethics, 83(3), 435-451. Retrieved from https://link.springer.com/article/10.1007/s10551-007-9630-y

14. Carpenter, M., Geletkanycz, M., \& Sanders, W. (2004). Upper echelons research revisited: Antecedents, elements, and consequences of top management team composition. Journal of Management, 30, 747778. Retrieved from http://journals.sagepub.com/doi/10.1016/j. jm.2004.06.001

15. Carter, D. A., D'Souza, F., Simkins, B. J., \& Simpson, W. G. (2010). The gender and ethnic diversity of US boards and board committees and firm financial performance. Corporate Governance: An International Review, 18(5), 396414.

16. Carter, D. A., Simkins, B. J., \& Simpson, W. G. (2003). Corporate governance, board diversity, and firm value. Financial Review, 38, 33-53. https://doi.org/10.1111/ j.1467-8683.2010.00809.x

17. Carter, S., Shaw, E., Lam, W., \& Wilson, F. (2007). Gender, entrepreneurship, and bank lending: The criteria and processes used by bank loan officers in assessing applications. Entrepreneurship Theory and Practice, 31(3), 427-444. https://doi.org/10.1111/j.15406520.2007.00181.x

18. Catanzariti, J., \& Lo, M. (2011). Corporate governance changes focus on diversity. Retrieved from http:// www.claytonutz.com/publications/newsletters/discrimination and-diversityinsights/20110511/ corporate_governance_changes_focus_on_diversity.page (accessed on November 12, 2017).

19. Chau, G., \& Gray, S. J. (2010). Family ownership, board independence and voluntary disclosure: Evidence from Hong Kong. Journal of International Accounting, Auditing and Taxation, 19(2), 93-109. Retrieved from http://ira.lib.polyu.edu.hk/handle/10397/28768 
20. Cheng, E. C., \& Courtenay, S. M. (2006). Board composition, regulatory regime and voluntary disclosure. The International Journal of Accounting, 41(3), 262289. Retrieved from https://econpapers.repec.org/RePEc:eee:accou n:v:41:y:2006:i:3:p:262-289

21. Daizy, \& Das, N. (2014). Sustainability reporting framework: Comparative analysis of global reporting initiatives and dow jones sustainability index. International Journal of Science, Environment and Technology, 3(1), 55-66. Retrieved from http://www. ijset.net/journal/493.pdf

22. Diamantopoulos, A., Schlegelmilch, B., Sinkovics, R., \& Bohlen, M. (2003). Can sociodemographics still play a role in profiling green consumers? A review of the evidence and an empirical investigation. Journal of Business research, 56(6), 465-480. Retrieved from https://econpapers. repec.org/article/eeejbrese/v_3a56_3ay_3a2003_3ai_3a6_3ap_ 3a465-480.htm

23. Dienes, D., \& Velte, P. (2016). The Impact of Supervisory Board Composition on CSR Reporting. Evidence from the German TwoTier System. Sustainability, MDPI, Open Access Journal, 8(1), 1-20. Retrieved from https://econpapers. repec.org/RePEc:gam:jsusta:v:8:y: 2016:i:1:p:63-:d:62004

24. Duztas, S. (2008). Corporate Governance the Effect of Board Characteristics, Information Technology Maturity and Transparency on Company Performance. Institute of Social Sciences Doctor of Philosophy (Management and Organization) İstanbul. Retrieved from http:// cgft.sabanciuniv.edu/sites/cgft. sabanciuniv.edu/files/220577.pdf

25. Elzahar, H., \& Hussainey, K. (2012). Determinants of narrative risk disclosures in UK interim reports. The Journal of Risk Finance, 13(2), 133-147. https://doi. org/10.1108/15265941211203189

26. Esa, E., \& Ghazali, N. (2012). Corporate Social Responsibility and Corporate Governance in
Malaysian Government-Linked Companies. Corporate Governance, 12(3), 292-305. https://doi. org/10.1108/14720701211234564

27. Ezhilarasi G., \& Kabra, K. C. (2017). The impact of corporate governance attributes on environmental disclosure in India. India journal of corporate governance, 10(1) Retrieved from http://journals.sagepub.com/doi/ abs/10.1177/0974686217701464

28. Fields, M. A., \& Keys, P. Y. (2003). The Emergence of Corporate Governance from Wall St to Main St: Outside Directors, Board Diversity, Earnings Management and Managerial Incentives to Bear Risk. Financial Review, 38(1), 1-24. https://doi.org/10.1111/15406288.00032

29. Gallén, M. L., \& Perait, C. (2017). The Relationship between Femininity and Sustainability Reporting, Corporate Social Responsibility and Environmental Management, 4, 1-13. https://doi. org/10.1002/csr. 1423

30. Giannetti, M., Liao, G., \& Yu, X. (2015). The Brain Gain of Corporate Boards: Evidence from China. The Journal of Finance, 70(4), 1629-1682. https://doi. org/10.1111/jofi.12198

31. Gisbert, A., \& Navallas, B. (2013). The association between voluntary disclosure and corporate governance in the presence of severe agency conflicts. Advances in Accounting, 29(2), 286-298. https://doi.org/10.1016/j.adiac.2013.07.001

32. Global Reporting Initiative (2011). Sustainability reporting guidelines. Retrieved from https://www.globalreporting.org/resourcelibrary/ G3.1-Guidelines-Incl-TechnicalProtocol.pdf

33. Haji, A. A. (2010). The trend of Corporate social responsibility Disclosures and the Role of Corporate Governance Attributes: The Case of Shari'ah Compliant Companies in Malaysia. Issues in Social \& Environmental Accounting, 6(3-4), 68-94.

34. Halil, E. A. (2016). The relationship between board characteristics and environmental disclosure: evidence from turkey listed companies' south-east. European journal of economics and business, 11(2), 7-19. https://doi. org/10.1515/jeb-2016-0007

35. Hamid, A., \& Atan, R. (2011). Corporate Social Responsibility by the Malaysian Telecommunication Firms. International Journal of Business and Social Science, 2(5). Retrieved from http:// ijbssnet.com/journals/Vol._2 No._5_\%5BSpecial_Issue_-March_2011\%5D/25.pdf

36. Hidalgo, R. L., Garcia-Meca, E., \& Martinez, I. (2011). Corporate governance and intellectual capital disclosure. Journal of Business Ethics, 100(3), 483-495. Retrieved from https://link.springer.com/article/10.1007/s10551-010-0692-x

37. Ismail, K., \& Ibrahim, A. H (2010) Social \& Environmental Disclosure in the annual Reports of Jordanian Companies. Issues in Social \& Environmental Accounting, 2, 198-210. Retrieved from https://www.researchgate. net/publication/264048085_Social_and_Environmental_Disclosure_in_the_Annual_Reports_of_ Jordanian_Companies

38. Jackson, S. E., Joshi, A., \& Erhardt, N. L. (2003). Recent Research on Team and Organizational. Retrieved from www.scirp.org/ (S(lz5mqp453edsnp55rrgjct55))/ reference/ReferencesPapers.aspx?

39. Jensen, M. C. (1993). The modern industrial revolution, exit and the failure of internal control systems. The Journal of Finance, 48(3), 831-880. Retrieved from https://onlinelibrary.wiley.com/ doi/abs/10.1111/j.1540-6261.1993. tb04022.x

40. Kathyayini, K., Tilt, C. A., \& Lester, L. H. (2012). Corporate governance and environmental reporting: an Australian study. Corporate Governance, 12(2), 143-163. https://doi org/10.1108/14720701211214052

41. Khan, A., Muttakin, M. B., \& Siddiqui, J. (2013). Corporate governance and corporate social responsibility disclosures: Evidence from an emerging economy. Journal of Business 
Ethics, 114(2), 207-223. https://doi. org/10.1007/s10551-012-1336-0

42. Khan, H. U. (2010). The effect of corporate governance elements on corporate social responsibility reporting: Empirical evidence from private commercial banks of Bangladesh. International Journal of Law and Management, 52(2), 82-109. https://doi. org/10.1108/17542431011029406

43. Kılıç, M., Kuzey, C., \& Uyar, A. (2015). The Impact of Ownership and Board Structure on Corporate Social Responsibility (CSR) Reporting in the Turkish Banking Industry. Corporate Governance, 15(3), 357-374. https://doi. org/10.1108/CG-02-2014-0022

44. Konrad, A. M., Kramer, V., \& Erkut, S. (2008). Critical mass: The impact of three or more women on corporate boards. Organizational Dynamics, 37(2), 145-164. https://doi.org/10.1016/j. orgdyn.2008.02.005

45. Krejcie, R. V., \& Morgan, D. W. (1970). Determining Sample Size for search Activities. Educational and psychological measurement, 30, 607-610. https://doi. org/10.1177/001316447003000308

46. Kruger, P. (2010). Corporate Social Responsibility and the Board of Directors. Retrieved from https:// www.sfgeneva.org/doc/110317_ kruegerCsrandBoard.pdf

47. Larmou, S., \& Vafeas, N. (2010). The relation between board size and firm performance in firms with a history of poor operating performance. Journal of Management \& Governance, 14(1), 61-85. Retrieved from https://link.springer.com/ article/10.1007\%2Fs10997-0099091-Z

48. Liao, L., Luo, L., \& Tang, Q. (2014). Gender diversity, board independence, environmental committee and greenhouse gas disclosure. The British Accounting Review, 47, 409-424. https://doi. org/10.1016/j.bar.2014.01.002

49. Lilik H., Bambang, S., Sutrisna, T., \& Erwin, S. (2014). Does Board Diversity Matter on Corporate Social Disclosure: An Indonesian
Evidence. Journal of economics and sustainable development, 9(4).

50. Lynall, M., Golden, B., \& Hilman, A. (2003). Board Composition from Adolescence to Maturity: A Multi-theoretic view. The Academy of Management Review, 28(3), 416-431. https://doi.org/10.5465/ amr.2003.10196743

51. MacKenzie, C. (2007). Boards, incentives and corporate social responsibility: the case for a change of emphasis. Corporate Governance: An International Review, 15(5), 935-943. Retrieved from https://econpapers.repec.org/ RePEc:bla:corgov:v:15:y:2007:i:5 :p:935-943

52. Mclkenny, P., \& Ben-Amar, W. (2015). Board effectiveness and voluntary disclosure of climate change information. Business Strategy and the Environment, 24(8), 704-719. https://doi. org/10.1002/bse. 1840

53. Mgbame, C. O. (2012). Environmental accounting audit in selected companies in Nigeria (Unpublished Ph.D. thesis submitted to the University of Benin). Retrieved from http:// www.sapub.org/global/showpaperpdf.aspx?doi $=10.5923 / \mathrm{j}$. ijfa.20150403.01

54. Michelle, P. S. (2016). Corporate Environmental Disclosure in Malaysian Public Listed Companies Msc Thesis Curtin University. Diversity: SWOT Analysis and Implications. Journal of Management, 29, 801-830.

55. Mohamad, W. W., \& Sulong, Z. (2010). Corporate governance mechanisms and extent of disclosure: Evidence from listed companies in Malaysia. International Business Research, 3(4), 216-228. https://doi. org/10.5539/ibr.v3n4p216

56. Mullen, E. (2011). Women in leadership promote corporate social responsibility. Retrieved from https://www.nacdonline.org/ insights/magazine/ (accessed on December 2012).

57. Natividad, I. (2005). Women directors and the global company. Directors Monthly, March 13-15.
58. Ntim, C. G., Lindop, S., \& Thomas, D. A. (2013). corporate governance and risk reporting in South Africa: A study of corporate risk disclosures in the pre-and post-2007/2008 global financial crisis periods. International Review of Financial Analysis, 30, 363-383. Retrieved from https:// papers.ssrn.com/sol3/Delivery. cfm?abstractid $=2289521$

59. Osariemen, A., Edosa, J. A., Uwuigbe, U., \& Uwuigbe, O. R. (2018). Audit committee attributes and audit quality: a benchmark analysis. Business: Theory and Practice, 19, 37-48. https://doi. org/10.3846/btp.2018.05

60. Olubukola, R. U., Uwuigbe, U., Jimoh, J., Ebeguki, E. I., \& Olufemi, A. O. (2016). Value relevance of financial statements and share price: a study of listed banks in Nigeria. Banks and Bank Systems, 11(4), 135-143. Retrieved from http://eprints.covenantuniversity.edu.ng/8431/1/Value_relevance_of_financial_statements_ share_pric.pdf

61. Othman, R., \& Rashid, A. (2009). Corporate social and environmental reporting: Where are we heading? A survey of the literature. International Journal of Disclosure and Governance, 6(4), 298-320.

62. Oyeshola, D. (2008). Sustainable development: issues and challenges for Nigeria. Daily Graphic Nigeria book. Retrieved from https://searchworks.stanford. edu/view/10457029

63. Pfeffer, J., \& Salancik, G. R. (1978). The External Control of Organizations: A Resource Dependence Perspective. New York, NY, Harper and Row. Retrieved from https://www.journals.uchicago.edu/doi/abs/10.1086/227517

64. Pramanik, A. K., Shil, N. C., \& Das, B. (2008). Corporate Environmental Reporting: An Emerging Issue in the Corporate World. International Journal of Business and Management, 3(12), 146-154. https://doi.org/10.5539/ ijbm.v3n12p146

65. Rahman, N., \& Post, C. (2012). Measurement issues in 
environmental corporate social responsibility ECSR): toward a transparent, reliable and construct valid instrument. Journal of Business Ethic, 105(3), 307-319. Retrieved from https://www.jstor. org/stable/41413219?seq=1\#page scan_tab_contents

66. Rose, C. (2007). Does female board representation influence firm performance? The Danish evidence. Corporate Governance: An International Review, 15(2), 404-413. https://doi.org/10.1111/ j.1467-8683.2007.00570.x

67. Rouf, M. (2011). Corporate characteristics, governance attributes and the extent of voluntary disclosure in Bangladesh. African Journal of Business Management, 5(19), 7836-7845.

68. Sadis, M., Tariq, A., \& Saba, S. (2015). The Effect of Corporate Governance Elements on Corporate Social Responsibility (CSR) Disclosure in Pakistan. Int. J. Financial Stud, 3(4), 530556. https://doi.org/10.3390/ ijfs3040530

69. Saha, A. K., \& Akter, S. (2013). Relationship between environmental reporting in corporate annual reports \& corporate profitability in Bangladesh. Global Conference on Business \& Finance Proceedings, 8(1), 75-86.

70. Schneider, T. E. (2010). Is environmental performance a determinant of bond pricing?
Evidence from the U.S. pulp and paper and chemical industries (Working Paper). Retrieved from http://papers.ssrn.com/sol3/papers.cfm?abstract_id=1299761

71. Selsky, J. W., \& Parker, B. (2005). Cross-Sector Partnerships to Address Social Issues: Challenges to Theory and Practice. Journal of Management, 31(6), 849-873. Retrieved from https://link. springer.com/article/10.1007/ s10551-011-0776-2

72. Sharfman, M., \& Fernando, C. (2008). Environmental risk management and the cost of capital. Strategic management journal, 29, 569-592. https://doi. org/10.1002/smj.678

73. Sharif, M., \& Rashid, K. (2014). Corporate governance and corporate social responsibility (CSR) reporting: an empirical evidence from commercial banks (CB) of Pakistan. Quality \& Quantity, 48(5), 2501-2521.

74. Strandberg, C. (2005). The convergence of corporate governance and corporate social responsibility: Though-Leader Study. Retrieved from www. corostranberg.com

75. Sun, N., Salama, A., Hussainey, K., \& Habbash, M. (2010). Corporate environmental disclosure, corporate governance and earnings management. Managerial Auditing Journal, 25(7), 679-700. https://doi. org/10.1108/02686901011061351
76. Tareq, B., Reza, K., \& Aminu, H. (2017). The impact of corporate characteristics on social and environmental disclosure: The case of Jordan. Journal of Accounting and Auditing; Research and Practice, 29. https:// doi.org/10.5171/2017.369352

77. Thompson, P., \& Zarina, Z. (2004). Corporate social responsibility reporting in Malaysia. Journal of Corporate Citizenship, 13, 125-136.

78. Uwuigbe, U. N., Egbide, B. C., \& Ayokunle, A. M. (2011). The effect of board size and board composition on firm's corporate environmental disclosure: a study of selected firms in Nigeria. Acta Universitatis Danubius, 7(5), 164176. Retrieved from http://journals.univ-danubius.ro/index.php/ oeconomica/article/view/1095

79. Uwuigbe, U., Agba, L. U., Jimoh, J., Olubukunola, R. U., \& Rehimetu, J. (2017). IFRS adoption and earnings predictability: evidence from listed banks in Nigeria. Banks and Bank Systems, 12(1), 166174. http://dx.doi.org/10.21511/ bbs.12(1-1).2017.10

80. Uwuigbe, U., Olusanmi, O., \& Iyoha, F. (2015). The Effects of Corporate Governance Mechanism on Firms Dividend Pay-out Policy in Nigeria. Journal of accounting and auditing: research \& practice. https://doi. org/10.5171/2015.313679 


\section{APPENDIX A}

Table A1. Regression result for panel data

Dependent variable: CSEDI

Method: panel least squares

Date: 05/10/18. Time: 22:40

Sample: 20122016

Periods included: 5

Cross-sections included: 17

Total panel (balanced) observations: 85

\begin{tabular}{l|c|c|c|c}
\hline \multicolumn{1}{c|}{ Variable } & Coefficient & Std. Error & T-statistic & Prob. \\
\hline BSIZE & 0.062542 & 0.007902 & 7.914699 & 0.0000 \\
FD & 0.264178 & 0.106705 & 2.475776 & 0.0155 \\
GENDER & 0.901495 & 0.132201 & 6.819119 & 0.0000 \\
\hline C & -0.354971 & 0.098411 & -3.607011 & 0.0005 \\
\hline
\end{tabular}

\begin{tabular}{|c|c|c|c|}
\hline C & -0.354971 & -3.607011 & 0.0005 \\
\hline \multicolumn{4}{|c|}{ Effects specification } \\
\hline \multicolumn{4}{|c|}{ Period fixed (dummy variables) } \\
\hline R-squared & 0.562567 & Mean dependent var & 0.545752 \\
\hline Adjusted R-squared & 0.522800 & S.D. dependent var & 0.270429 \\
\hline S.E. of regression & 0.186811 & Akaike info criterion & -0.428047 \\
\hline Sum squared resid & 2.687179 & Schwarz criterion & -0.198150 \\
\hline Log likelihood & 26.19199 & Hannan-Quinn critter & -0.335576 \\
\hline F-statistic & 14.14671 & Durbin-Watson stat & 0.408366 \\
\hline Prob (F-statistic) & 0.000000 & & - \\
\hline
\end{tabular}

Dependent variable: CSEDI

Method: panel EGLS (period random effects)

Date: 05/10/18. Time: 22:42

Sample: 2012-2016

Periods included: 5

Cross-sections included: 17

Total panel (balanced) observations: 85

Swamy and Arora estimator of component variances

\begin{tabular}{|c|c|c|c|c|}
\hline Variable & Coefficient & Std. error & T-statistic & Prob. \\
\hline BSIZE & 0.060756 & 0.007841 & 7.749015 & 0.0000 \\
\hline $\mathrm{FD}_{-.}$ & 0.241031 & 0.105780 & 2.278614 & 0.0253 \\
\hline GENDER & 0.866844 & 0.130461 & 6.644484 & 0.0000 \\
\hline C & -0.322695 & 0.096829 & -3.332628 & 0.0013 \\
\hline \multicolumn{5}{|c|}{ Effects specification } \\
\hline & & & S.D. & Rho \\
\hline Period random & & & 0.000000 & 0.0000 \\
\hline Idiosyncratic random & & & 0.186811 & 1.0000 \\
\hline \multicolumn{5}{|c|}{ Weighted statistics } \\
\hline R-squared & 0.543172 & \multicolumn{2}{|c|}{ Mean dependent var } & 0.545752 \\
\hline Adjusted R-squared & 0.526252 & \multicolumn{2}{|c|}{ S.D. dependent var } & 0.270429 \\
\hline S.E. of regression & 0.186134 & \multicolumn{2}{|c|}{ Sum squared resid } & 2.806325 \\
\hline F-statistic & 32.10318 & \multicolumn{2}{|c|}{ Durbin-Watson stat } & 0.386051 \\
\hline Prob (F-statistic) & 0.000000 & \multicolumn{2}{|c|}{-} & - \\
\hline \multicolumn{5}{|c|}{ Unweighted statistics } \\
\hline R-squared & 0.543172 & \multicolumn{2}{|c|}{ Mean dependent var } & 0.545752 \\
\hline Sum squared resid & 2.806325 & \multicolumn{2}{|c|}{ Durbin-Watson stat } & 0.386051 \\
\hline
\end{tabular}

